\title{
GLACIER VARIATIONS IN THE EUROPEAN ALPS AT THE END OF THE LAST GLACIATION
}

\section{S. IVY-OCHS}

Laboratory of Ion Beam Physics, ETH Zurich, 8093 Zurich. Department of Geography, University of Zurich, 8057 Zurich.

\begin{abstract}
The Last Glacial Maximum in the Alps lasted from approximately 30 to $19 \mathrm{ka}$. Glaciers reached out onto the forelands on both sides of the main Alpine chains, forming piedmont lobes in the north and filling the Italian amphitheatres to the south. Pullback of glaciers from their maximum extent was underway by $24 \mathrm{ka}$. Glaciers oscillated at stillstand and minor re-advance positions for several thousand years forming Last Glacial Maximum (LGM) stadial moraines. North and south of the Alps, the various stadials cannot yet be unequivocally matched. Glaciers had receded back within the mountain front by 19-18 ka. During the early Lateglacial phase of ice decay remnants of the once huge valley glaciers that fed the piedmont lobes downwasted and were likely calving into the extensive lakes that formed in the lower valley reaches. The first Alpine-wide glacier re-advance took place during the Gschnitz stadial, 17-16 ka, which was likely a response to Europe-

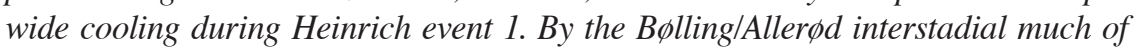
the Alps were ice-free. Glaciers advanced repeatedly to an extent several kilometers from the cirque headwalls, during the Egesen stadial in response to the Younger Dryas cold period. Egesen stadial moraines, at some sites several sets of moraines, were constructed in valleys all across the Alps. ${ }^{10}$ Be exposure dates for Egesen stadial moraines are in the range 13.5 to $12 \mathrm{ka}$. Moraines located at an intermediate position between the Little Ice Age moraines and the Egesen moraines formed at the margins of glaciers that advanced during the closing phase of the Egesen stadial or during the earliest Holocene at $10.5 \mathrm{ka}$.
\end{abstract}

\section{Variaciones glaciares en los Alpes europeos al final de la última glaciación}

RESUMEN. El último máximo glaciar en los Alpes duró desde aproximadamente 30 a $19 \mathrm{ka}$. Los glaciares alcanzaron la parte más externa de ambos lados de las principales cadenas alpinas, formando lóbulos de piedemonte en el norte y rellenando los anfiteatros italianos en el sur. El parón de los glaciares desde su máxima extensión ocurrió no más tarde de $24 \mathrm{ka}$. Los glaciares oscilaron con pequeños reavances durante varios miles de años, dando lugar a las morrenas estadiales del Último Máximo Glaciar. Al norte y al sur de los Alpes los diferentes estadiales no presentan una exacta correspondencia. Los glaciares retrocedieron 
hacia el interior de la montaña hacia 19-18 ka. Durante la fase más temprana de retroceso del hielo en el Tardiglacial los lóbulos de hielo que llegaban hasta el piedemonte, fundieron en los extensos lagos que se formaron en los tramos inferiores de los valles. El primer reavance glaciar alpino tuvo lugar durante el estadial Gschnitz, 17-16 ka, que fue probablemente la respuesta al enfriamiento

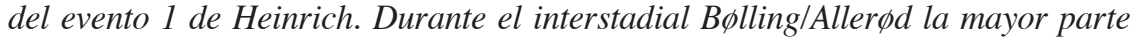
de los Alpes estaba libre de hielo. Los glaciares avanzaron repetidamente con una extensión de varios kilómetros desde la cabecera de los circos durante el estadial Egesen como respuesta al periodo frío del Younger Dryas. Las morrenas Egesen, en algunos sitios varios conjuntos de morrenas, fueron construidas en muchos valles de los Alpes. Las fechas cosmogénicas $\left({ }^{10} \mathrm{Be}\right)$ de las morrenas del estadial Egesen se han datado entre 13,5 y $12 \mathrm{ka}$. Las morrenas situadas en una posición intermedia entre las morrenas de la Pequeña Edad del Hielo y las morrenas Egesen se formaron en las márgenes de glaciares que avanzaron durante la última etapa del estadial Egesen o a comienzos del Holoceno, hace 10,5 ka.

Keywords: last glacial maximum, lateglacial, Gschnitz, Egesen, Holocene, cosmogenic nuclides.

Palabras clave: último máximo glacial, tardiglaciar, Gschnitz, Egesen, Holoceno, nucleidos cosmogénicos.

Received 12 April 2015

Accepted 29 April 2015

*Corresponding author: Laboratory of Ion Beam Physics, ETH Zurich, 8093 Zurich, Switzerland. E-mail: ivy@phys.ethz.ch

\section{Introduction}

The Alps and the Jura Mountains played a key role in the birthplace of the Ice Age theory (Krüger, 2008, and references therein). In the Alps, as well as in Scandinavia and the UK, the heart of the question was the origin of the erratics. How could huge blocks of granite be transported away from their original bedrock outcrops in the Alps and be deposited on the limestone bedrock of the Jura? The elevation where many granitic erratics are presently located is up to almost $1400 \mathrm{~m}$ a.s.l., while the floor of the valley which lies between the Alps and the Jura lies at about $400 \mathrm{~m}$ a.s.l. Perraudin, a hunter in Oberwallis, observed that glaciers carried huge amounts of debris and left it at the margins as moraines. He realized that moraines further downvalley must record earlier, greater extents of the same glacier. He discussed his ideas with Venetz who then convinced both de Charpentier and Agassiz. The latter became an enthusiast and now is one of the bestremembered proponents of the Ice Age theory (Krüger, 2008 and references therein). Penck and Brückner (1909) provided a particularly comprehensive overview of the state of research in the early $20^{\text {th }}$ century on the glaciations of the Alps. They introduced the concept of four glaciations; Günz, Mindel, Riss, and Würm. While an extended version 
of the four-fold system is maintained in the forelands of the Eastern Alps (Fiebig et al., 2011 and references therein), in the Swiss sector to the west it has been abandoned. At least 15 glaciations are suggested to have occurred since the beginning of the Quaternary at $2.58 \mathrm{Ma}$ (Schlüchter, 1988, 2004). Extreme changes in base level related to the Alpine Rhine draining either predominantly to the east to the Danube or to the west into the Rhine graben resulted in a more complex aggradation and incision configuration than on the eastern Alpine outwash plains (Kuhlemann and Rahn, 2013).

For nearly two centuries, the past extents of glaciers in the Alps have been estimated based on mapping of moraines and other ice-marginal landforms, in conjunction with detailed study of associated sediments. Changes in equilibrium line altitudes (ELA) of glaciers are an excellent proxy of changes in climatic conditions at the time; allowing estimation of increases or decreases in summer temperature or precipitation sums (Kerschner, 2009 and references therein). In the Alps, paleo-ELA's are based on glacier surface reconstruction and an ablation area ratio of 0.67 (Gross et al., 1977; Maisch et al., 2000; Kerschner, 2009). In this paper we summarize the present state of knowledge on the end of the last glaciation and the Alpine Lateglacial stadials including recent mapping and dating results. The timing of moraine construction has been constrained at several sites with ${ }^{10} \mathrm{Be}$ surface exposure dating and radiocarbon dating of organic material in associated sediments. All previously published ${ }^{10} \mathrm{Be}$ exposure ages discussed here are recalculated based on the NE North America ${ }^{10} \mathrm{Be}$ production rate (Balco et al., 2009) with the Lm (Lal/magnetic) scaling system. For detailed locations of dated moraines and boulders the original references should be consulted. Radiocarbon dates are calibrated with OXCAL4.2 with the INTCAL13 data set (Reimer et al., 2013) and are listed as calibrated age ranges (ka cal BP). Measured radiocarbon dates are found in the given references. For discussion all dates are presented as ka, the ${ }^{10} \mathrm{Be}$ ages and calibrated radiocarbon dates result in well comparable time scales.

\section{Last Glacial Maximum stadials and termination}

Reaching of the maximum extent on both the northern and southern side of the Alps occurred during MIS2, in concert with the global Last Glacial Maximum between 26 and 19 ka (Clark et al., 2009; Shakun and Carlson, 2010; Hughes et al., 2013). A steep drop in sea level reflecting increasing global ice volumes at around $30 \mathrm{ka}$ with a more gradual lowering until to $20 \mathrm{ka}$, was followed by a stepwise rise during the Lateglacial and early to middle Holocene (Lambeck et al., 2014 and references therein). Reaching of the maximum ice extent on the Alpine forelands during the last glacial cycle is constrained by mapping of the outermost 'fresh' or Jungmoränen (Penck and Brückner, 1909) and their associated outwash deposits (so-called Niederterrassen). The moraines formed during the last glaciation are distinguished from older morphologically less distinct outboard moraines attributed to penultimate glacier expansions during MIS 6 or 8 (Graf, 2009; Keller and Krayss, 2010; Preusser et al., 2011; Fiebig et al., 2011; Gianotti et al., 2015). Records from sites on both the northern and southern side of the Alps suggest advance of glaciers beyond the Alpine front at around $30 \mathrm{ka}$ ago (Keller and Krayss, 2005; Monegato et al., 2007; Scapozza et al., 2015). 


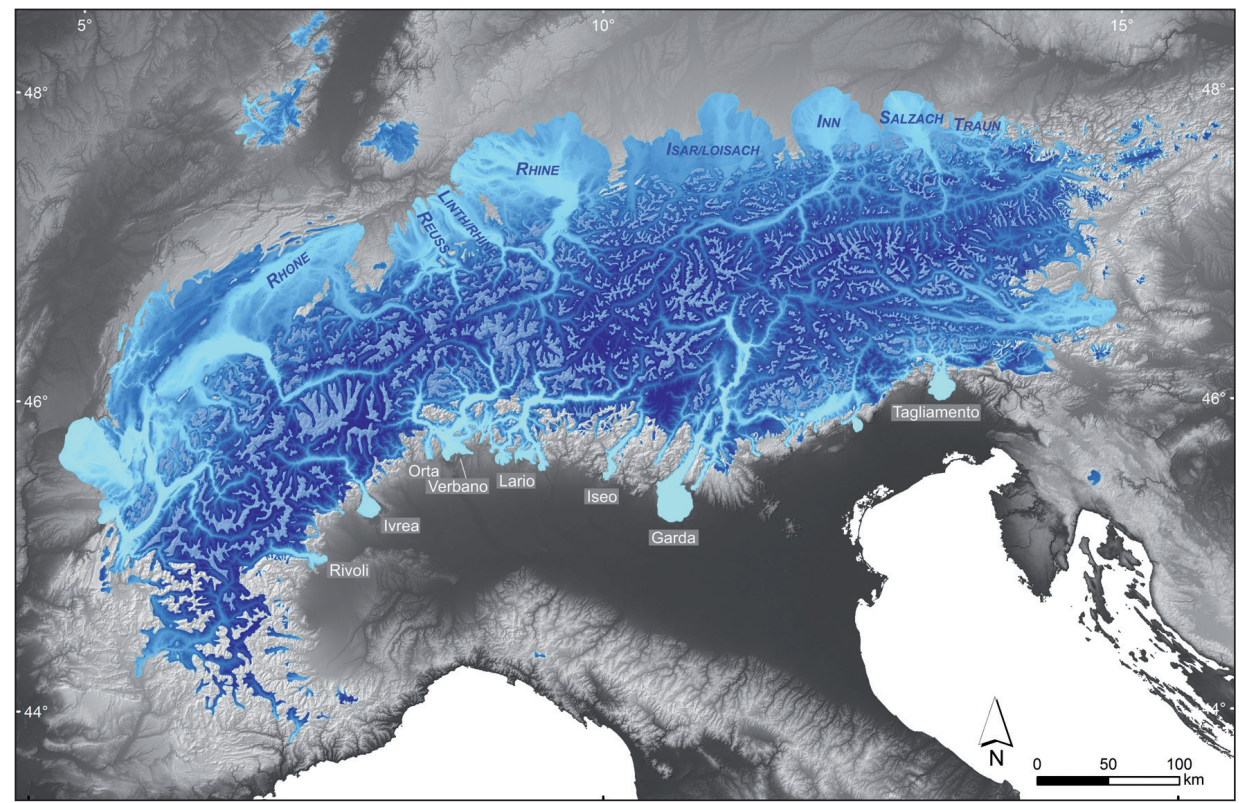

Figure 1. The Alps during the Last Glacial Maximum (late Wïrm). Ice extent taken from Ehlers and Gibbard (2004). At specific locations the present understanding of the LGM ice margin or ice surface height may differ in detail from this depiction. Piedmont lobes and Italian amphitheatres are labelled.

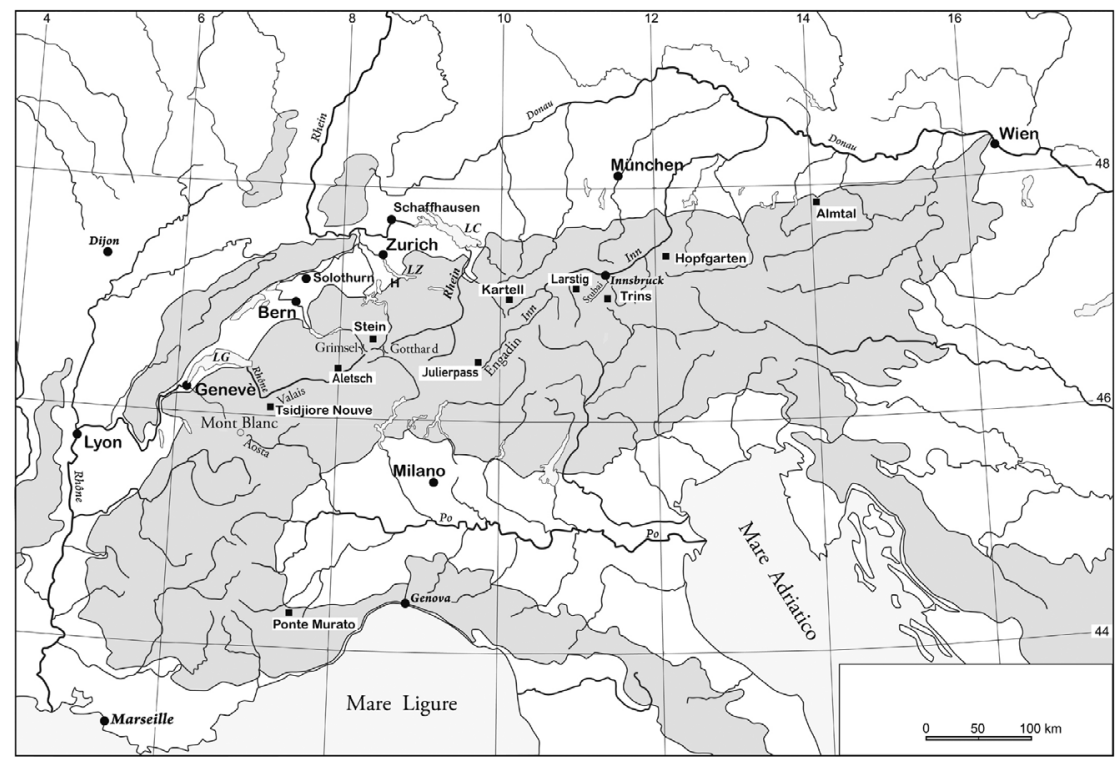

Figure 2. Index map of the European Alps showing locations discussed in the text. Areas above $700 \mathrm{~m}$ a.s.l. are shaded grey (modified from Ivy-Ochs et al., 2009). $L G=$ Lake Geneva, $L Z=$ Lake Zurich, LC= Lake Constance, $H$ stands for Hohronen. 
During the Last Glacial Maximum in the European Alps (late Würm) local ice caps and extensive ice fields in the high Alps fed huge outlet glaciers that occupied the main valleys, for example, the Rhone, Reuss, Rhine, Inn, and Salzach in the northern sector and the Tagliamento, Piave, Sarca, Ticino, Dora Baltea, and Dora Riparia along the southern side (Figs. 1 and 2). Systems of transection glaciers with transfluences over many of the Alpine passes existed during the LGM (Florineth and Schlüchter, 1998; Kelly et al., 2004a; Bini et al., 2009), for example at Grimsel Pass (Fig. 3) where Rhone glacier ice flowed northward into the Aare glacier catchment. Geological evidence, such as bedrock ice-flow direction mapping, trimline mapping and locations of high elevation erratics, points to thicker ice to the south of the main (present-day) water divide (Florineth and Schlüchter, 2000; Hippe et al., 2014; Wirsig et al., submitted).

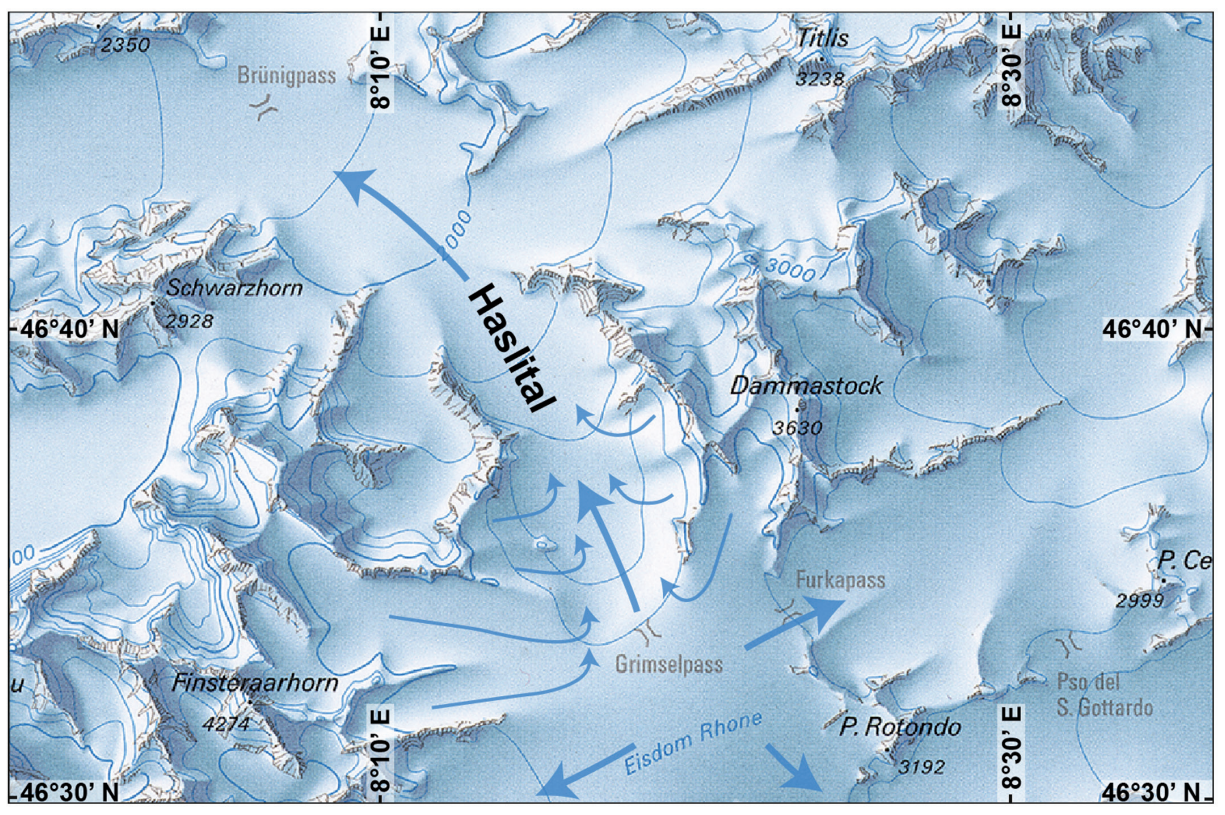

Figure 3. Excerpt from the LGM map of Bini et al. (2009) showing ice extent during the LGM for the Haslital area of central Switzerland (located just slightly to the north of Grimsel Pass which is indicated on Fig. 2).

The LGM Rhone glacier comprised a northern Solothurn lobe and a southern Geneva lobe (Figs. 1 and 2). The Solothurn lobe reached its furthest extent in the region of Wangen a.d. Aare as marked by broad, moraine ridges and till mantling Molasse bedrock highs. ${ }^{10} \mathrm{Be}$ exposure dates for boulders of hornblende granite brought from the southern valleys of the Valais located along the right lateral position indicate initial glacier withdrawal no later than $24 \pm 2 \mathrm{ka}$ (Ivy-Ochs et al., 2004). To the southwest, the Rhone glacier filled the Lake Geneva basin during the LGM and extended southward where it encountered the Isère, Arve and Arc glaciers whose end moraines make up the systems to the east of Lyon (Coutterand and Buoncristiani, 
2006; Coutterand et al., 2009). Based on seismic stratigraphy and core sediment studies in the Lake Geneva basin submerged moraines marking LGM stadial Rhone glacier positions have been recognized (Girardclos et al., 2005; Fiore et al., 2011). The Jura Mountains hosted a local ice cap during the LGM (Buoncristiani and Campy, 2011) that downwasted with timing similar to the Rhone glacier (Ndiaye et al., 2014). The Reuss glacier comprised long narrow finger like lobes confined by the intervening Molasse ridges in the Swiss forelands in the region between the Rhone Solothurn lobe and the Linth-Rhine lobe. Reber et al. (2014) obtained a minimum ${ }^{10} \mathrm{Be}$ age of $22 \pm 1 \mathrm{ka}$ for withdrawal of the Reuss glacier from the maximum end moraines. Keller and Krayss (2005) estimate Rhine glacier reaching of the maximum extent at Schaffhausen at no later than $24 \mathrm{ka}$ cal BP.

Glaciers on the northern Alpine forelands retreated step-wise with intervening stillstands or minor re-advances discussed as the LGM stadials (Hantke, 1978). Eight moraine chains attributed to three LGM stadials have been discussed for the Rhine glacier (Keller and Krayss, 2005). The several well-preserved lateral moraines along the left side of Lake Zurich mark the ice margin fluctuations during the Zurich stadial (Fig. 4). Between the outermost Killwangen stadial position and the Zurich position, the Linth-Rhine glacier halted at the Schlieren position (Keller and Krayss, 2005). A piece of wood in delta sediments deposited in the lake formed between the Schlieren and Zurich stadial moraines was radiocarbon dated to 24.3 to $23.4 \mathrm{ka}$ cal BP. Schlüchter and Röthlisberger (1995) place this as a maximum age for the Zurich stadial re-advance. Sediments reported in the early part of the last century but subsequently removed during quarrying and construction of the road dam across Lake Zurich suggested a brief stillstand at Hurden. This may record the terminus of a floating ice tongue pinned on the bedrock bench that separates the upper and lower Lake Zurich basins (Hantke, 19781983; Graf, 2009). The oldest radiocarbon date from wood in Lake Zurich cores suggests a minimum age of 18.4-17.1 ka cal BP for an ice-free lake basin (Lister, 1988). In the Austrian sector, the age of a piece of wood from the Rödschitz site shows retreat of the Traun glacier (Fig. 1) to inside the mountain front by 19.8-17.6 ka cal BP (van Husen, 1997).

Data from several of the Italian amphitheatres suggest that LGM glaciers were at their most advanced position of the last glacial cycle between 27 and $21 \mathrm{ka} \mathrm{cal} \mathrm{BP}$ (Monegato et al., 2007; Ravazzi et al., 2012 and references therein). Based on lithostratigraphy and pollen study underpinned by ${ }^{14} \mathrm{C}$ dating, a two-phase LGM maximum extent has been recognized at the Tagliamento glacier amphitheatre (Fig. 1). Monegato et al. (2007) found that the first advance, the Santa Margherita advance, took place between 26.5 and $23 \mathrm{ka}$ cal BP. The second advance, the Canodusso advance, where the glacier nearly reached its previous extent, was between 24 and $21 \mathrm{ka}$ cal BP. The Remanzacco recessional moraines were constructed between 21 and $19 \mathrm{ka}$ cal BP.

Starnberger et al. (2011 and references therein) discuss three end moraine systems of the LGM Salzach glacier in southern Germany and adjacent Austria. The authors describe an outermost, Nunreuter phase, the recessional Radegunder phase, and the innermost minor re-advance Lanzinger phase. Luminescence dating suggests that the 
second phase, which occurred between 21-20 ka, may correlate to the Canodusso phase of the Tagliamento amphitheatre (Starnberger et al., 2011).

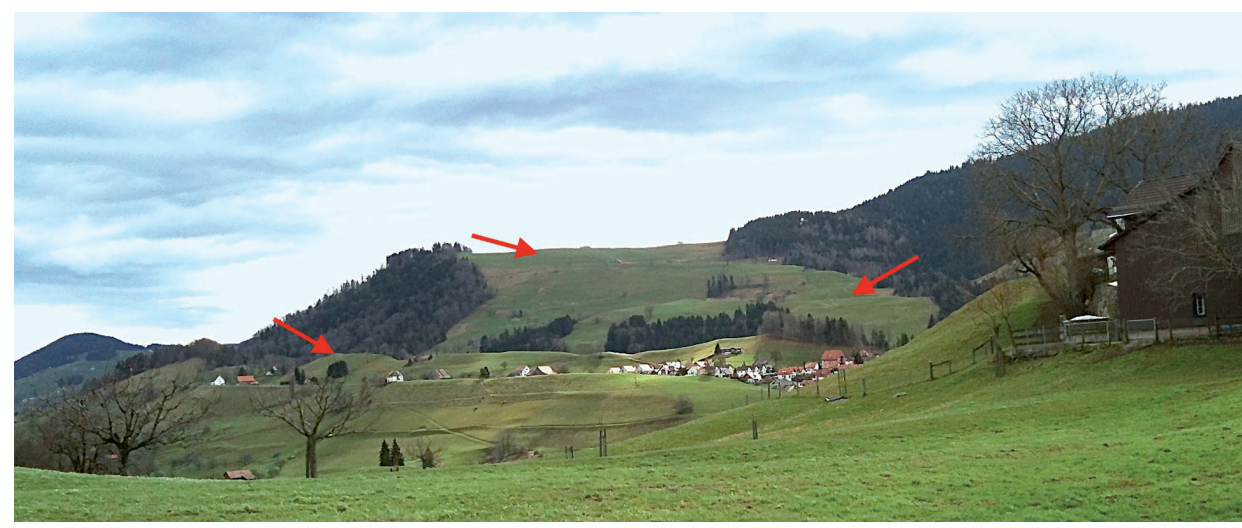

Figure 4. Photograph of LGM stadial moraines on the left-lateral side of the Linth-Rhine glacier in the Lake Zurich region. View is to the SSE towards the Hohronen (labelled H in Fig. 2). The uppermost meadow is the Rossberg (1010 m a.s.l.), mapped as pre-LGM glacial sediments ('Riss') (Hantke, 1978). The moraine indicated by the upper red arrow is at $950 \mathrm{~m}$ a.s.l. and closely approximates the maximum LGM ice surface height (Bini et al., 2009). The lowermost arrow points to a Zurich stadial moraine (780 $\mathrm{m}$ a.s.l.), just below it lies an inner Zurich stadial moraine (740 $\mathrm{m}$ a.s.l.). The hills in the right foreground belong to recessional stages of the Zurich stadial.

The Dora Baltea glacier whose headwaters lie in the Mt. Blanc massif filled Val d'Aosta and terminated in the Ivrea amphitheatre. The largest moraine, the Serra d'Ivrea, has been attributed to pre-last glacial cycle glaciations (Gianotti et al., 2008; 2015). At Ivrea, Gianotti et al. (2008, 2015) report four stadials for the LGM; named Pavone, Bienca, Prà San Pietro and Germano stadials. The ${ }^{10} \mathrm{Be}$ dates from the LGM moraines of the Ivrea amphitheatre indicate that pullback from the outermost Pavone moraines was underway by $24 \pm 2 \mathrm{ka}$ (Gianotti et al., 2015). Similar ${ }^{10} \mathrm{Be}$ ages were obtained for the timing of construction of the LGM moraine in the Gesso River valley in the Italian Maritime Alps (Federici et al. 2011; submitted). Based on a compilation of radiocarbon dates, Scapozza et al. (2015) estimate that the Ticino and Adda glacers reached their LGM furthest extent between 28.5 and $22.9 \mathrm{ka}$ cal BP. At Lake Iseo, ice-free conditions after downwasting of the Oglio glacier ensued no later than 18.6 to $17.9 \mathrm{ka}$ cal BP (Ravazzi et al., 2012; Baroni et al., 2014). Ravazzi et al. (2014) suggest LGM Sarca glacier collapse in the Garda Lake region was underway by 17.7 and $17.2 \mathrm{ka}$ cal BP. Dating of the timing of shutdown of sediment delivery to the distal outwash plain in the Friuli region at around 20.4 to 19.5 ka delineates the moment of withdrawal of the Tagliamento glacier from the LGM moraine complex (Fontana et al., 2014b). Along the southern forelands a similar timing for cessation of delivery of glaciofluvial sediments to megafans and the onset of incision into fan deposits is noted (Carton et al., 2009; Fontana et al., 2014a). 


\section{The Alpine Lateglacial}

The Alpine Lateglacial began when glaciers had receded back behind the mountain front; collapse of the piedmont lobes in the north and withdrawal from the amphitheatres in the south. The Alpine Lateglacial, 19-11.6 ka, comprised the Oldest Dryas cold period, Bølling warm period, Older Dryas cold period, Allerød warm period, and Younger Dryas cold period (e.g. Ammann et al., 1994). During this time glaciers advanced repeatedly as recorded by moraines in many Alpine valleys. Penck and Brückner (1909) proposed a three-fold division of the Lateglacial; the Bühl, Gschnitz, and Daun stadials. This system was extended and modified and the sequence from oldest to youngest Bühl, Steinach, Gschnitz, Clavadel/Senders, Daun, Egesen became an accepted paradigm (Kerschner, 2009 and references therein). Moraines are assigned to a stadial according to their relative position in a valley sequence, their morphological character and their ELA-depression relative to the Little Ice Age (LIA) ELA (Maisch et al., 2000 and references therein) (Table 1). The system is based on the idea that moraines in comparable morphostratigraphic positions, with similar morphologic characteristics, and similar ELA depressions located within a homogeneous climatic region were deposited during the same glacier advance period at around the same time.

Stagnant, downwasting remnants of the LGM glaciers filled the main valleys during the earliest Lateglacial. This period, which formerly comprised the Bühl and Steinach Lateglacial stadials (Penck and Brückner, 1909; Mayr and Hueberger, 1968), is now called the phase of early Lateglacial ice decay (Reitner, 2007). Based on detailed geomorphological and sedimentological study at the Bühl type locality in the Hopfgarten region, Reitner (2007) concluded that the ice-marginal positions at that site do not record climate-driven glacier readvances. Ice-marginal landforms, especially kame terraces (van Husen, 2000) that built up along the sides of the decaying ice masses, indicate that the glaciers were no longer responsive to climate signals from the accumulation areas (Reitner, 2007). Luminescene dating constrains this period to $17 \pm 2 \mathrm{ka}$ (Klasen et al., 2007). In smaller catchments, for example in the Alpstein area of eastern Switzerland, early Lateglacial climate-related re-advances are reported (Keller and Krayss, 2005). Re-calculation of the ${ }^{10} \mathrm{Be}$ exposure dates from the Ponte Murata moraine in the Italian Maritime Alps and ELA determinations suggest a re-advance at around $18.5 \mathrm{ka}$ that may be attributable to the Bühl stadial (Federici et al., submitted). The Magland-Tour Noire stage of the Arve glacier with an ELA depression of $800-850$ and ${ }^{10} \mathrm{Be}$ dated to $18 \mathrm{ka}$ may have formed during this phase of the early Lateglacial (Coutterand and Nicoud, 2005). ${ }^{10}$ Be ages on glacially striated bedrock located about $30 \mathrm{~km}$ upstream from the end moraines at Ivrea of 17-16 ka provide minimum ages for an ice-free lower Val d'Aosta (Gianotti et al., 2008, 2015).

The main valleys, for example the Rhone, Rhine, and Inn, are markedly overdeepened, with bedrock surfaces well below sea level at some points (Hinderer, 2001; Preusser et al., 2010; Reitner et al., 2010; Durst Stücki and Schlunegger, 2013). Lack of dating of the valley fill makes estimation of the elevation of the valley floors at the time of LGM ice decay difficult. Thickness of post-LGM valley fill varies significantly both between and within valleys (Müller, 1999; Hinderer, 2001; Preusser et al., 2010). 


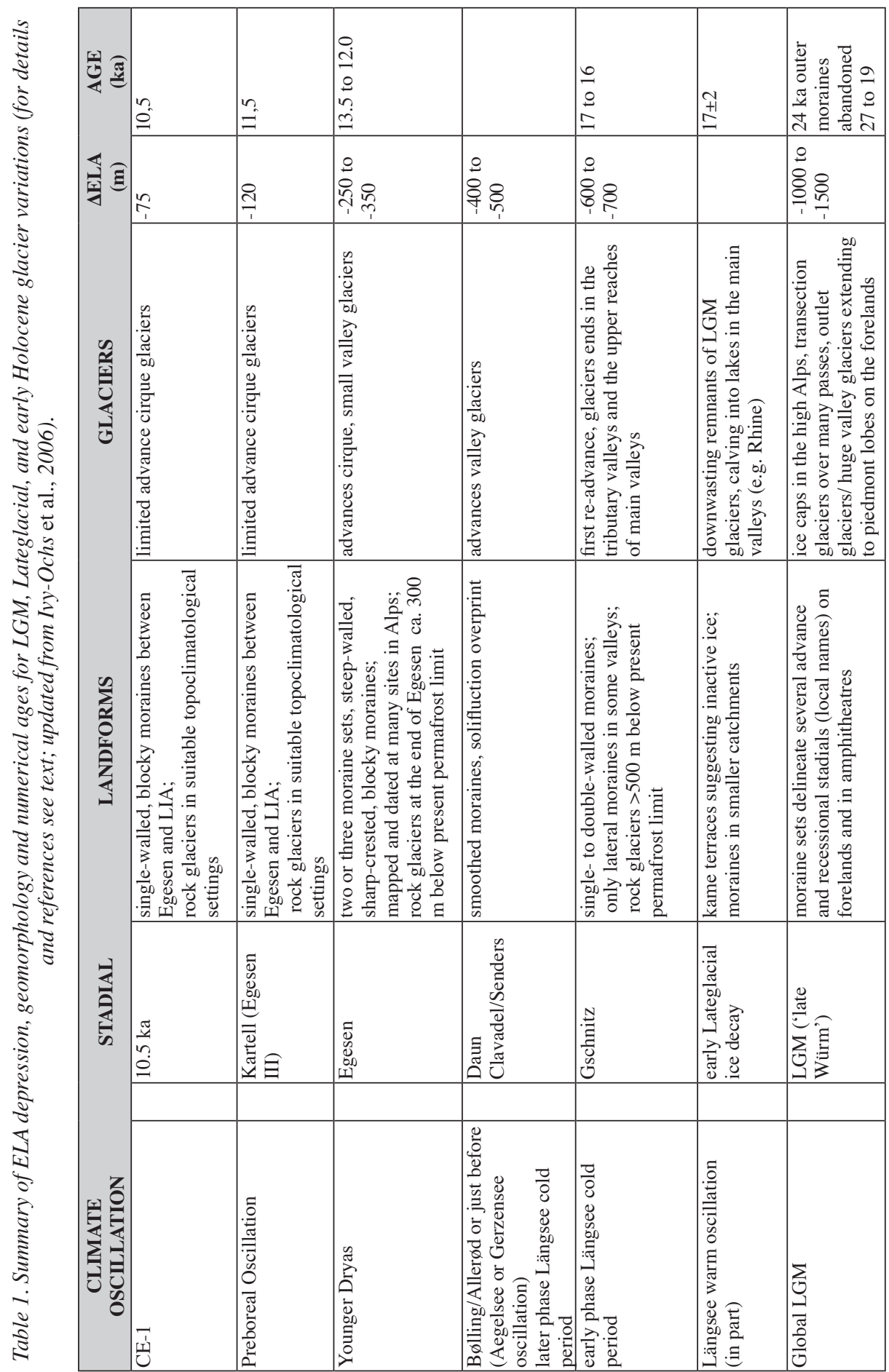


Müller (1999) suggests that in the region of the Rhine glacier diffluence at Sargans most pre-existing valley fill was eroded during the LGM; little of the pre-Last glacial cycle sediment remains at depth in the Rhine valley (Hinderer, 2001). The deepest sediments are a thin layer of till followed by hundreds of meters of lake sediment with dropstones suggesting the Rhine glacier was calving into a lake in the earliest Lateglacial, although the lake sediment remains undated. This lake, with a suggested level of $420 \mathrm{~m}$ a.s.l. (few to tens of meters higher than the present levels of Lake Zurich or Lake Constance), likely extended at least all the way up to Chur. A Lateglacial lake encompassing the present Lake Constance, Walensee and Lake Zurich has been suggested (Graf and Müller, 1999). In the delta and alluvial fan gravels that overlie the lake sediments in the upper Walensee reach, at a core depth of $39 \mathrm{~m}$ below surface, a piece of wood was dated at 14.9 to 13.9 ka cal BP (Müller, 1999).

It is likely that parts of the oversteepened and suddenly ice-free valley flanks collapsed in huge rock avalanches (van Husen, 2000). For example at Almtal (Fig. 2), the oldest dated landslide in the Alps (van Husen et al., 2007). Nevertheless, ${ }^{36} \mathrm{Cl},{ }^{10} \mathrm{Be}$ and ${ }^{14} \mathrm{C}$ dating has shown that none of the huge Alpine landslides (Flims, Koefels) recognizable at the surface today was ever in contact with a glacier (e.g. von Poschinger and Haas, 1997). Early Lateglacial rock slope failures may be represented by the cavernous niches along the valley walls, such as those present in the Rhone valley (Pedrazzini et al., 2015). Their deposits may lie below the hundreds of meters of post-glacial valley fill.

The Gschnitz stadial represents the first real glacier re-advance as shown by sites where Lateglacial till overlies early Lateglacial mass movement deposits or outwash (van Husen, 1997). Preserved moraine evidence shows that Gschnitz stadial glaciers occupied large areas in the principal tributary valleys and in the upper reaches of the main valleys. The type locality of the Gschnitz stadial moraine at Trins (Fig. 2) in the Gschnitz valley (Penck and Brückner, 1909), was ${ }^{10} \mathrm{Be}$ exposure dated to 17-16 ka (Ivy-Ochs et al., 2006). ELA depression during the Gschnitz stadial was 600-700 $\mathrm{m}$ in comparison to the LIA ELA. The Clavadel/Senders and Daun stadials lie between the Gschnitz and Egesen stadials (Kerschner, 2009 and references therein).

Key records for the early Alpine Lateglacial come from lakes Längsee and Jerzersee in southern Austria (Schmidt et al., 2009, 2012). In cores from Längsee, based on diatom and paleobotanical evidence constrained by radiocarbon dates from bulk gyttja, a warm period termed the Längsee oscillation (18.5 to $18.1 \mathrm{ka}$ cal BP) was identified (Huber et al., 2010). This was followed by a cold period that lasted until the beginning of the Bølling/Allerød interstadial. The Längsee cold period between 17.5 and $14.6 \mathrm{ka}$ cal BP may have consisted of two cold intervals separated by an intervening slightly warmer period. It is suggested that the earlier of the Längsee cold intervals (17.6 to $16.9 \mathrm{ka} \mathrm{cal}$ BP) is linked with the Gschnitz stadial (Schmidt et al., 2009, 2012; Huber et al., 2010).

Recognition of an Oldest Dryas pollen signal and the transition from Oldest Dryas to Bølling has been reported from numerous sites in the Alps (Burga, 1998). ${ }^{10} \mathrm{Be}$ exposure dating of glacially striated bedrock shows that no later than the beginning of Bølling the LGM ice surface had lowered to the extent that ice ceased to move across the main 
transfluence passes in the high Alps (Ivy-Ochs et al., 2006, Kelly et al., 2006; Dielforder and Hetzel, 2014; Hippe et al., 2014; Wirsig et al., submitted). Sedimentological and paleobotanical studies of lake and bog sediments show that not only the main valleys but also the tributary valleys were ice-free at the beginning of the Bølling or just before. This is confirmed by radiocarbon dates that calibrate to between 15.9 and $14.3 \mathrm{ka}$ cal BP from sites all across the Alps (Maisch, 1987; van Husen, 1997; Keller and Krayss, 2010; Ivy-Ochs et al., 2006; Kelly et al., 2006; Baroni et al., 2014; Heiri et al., 2014).

Daun stadial moraines often lie just downvalley from Egesen stadial moraines. They differ from the latter in having relatively broad, smoothed ridges that are poor in boulders. Consequently, they are conspicuously difficult to exposure date. Palynological data as well as ${ }^{14} \mathrm{C}$ dates on bulk sediment from the Albula region led to the conclusion that Daun moraines relate to an advance prior to the beginning of the Bølling warm period (Maisch, 1987). Van Husen (2000) correlates Daun advances to the Older Dryas, that lies between the Bølling and Allerød warm periods. In that case, the Daun stadial may correlate to either the Aegelsee (Older Dryas) or the Gerzensee (Intra-Allerød) cold pulse, which were recognized by del $^{18} \mathrm{O}$ and paleobotanical evidence from lakes in northwest Swiss forelands (Lotter et al., 1992, 2012; Ammann et al., 2013).

Egesen stadial moraines (Mayr and Heuberger, 1968) are relatively abundant and easy to locate in many Alpine valleys. They are recognizable as steep-walled, blocky moraine sets located several kilometers downvalley from the LIA moraines. ELA depression with respect to the LIA ELA is between 250-350 m. Somewhat higher ELA depressions are reported from sites on the northern fringes of the Alps (Kerschner et al., 2000) as well as from the Maritime Alps (Federici et al., 2009, submitted). The Egesen stadial glacier advances are linked to the Younger Dryas cold period (Ivy-Ochs et al., 2009 and references therein). The period of extreme climate fluctuations led to construction of two to three groups of moraines at some glaciers (Maisch, 1987). The first two are termed Egesen maximum and Bocktentälli. At Julier Pass (Fig. 2), the Egesen Lagrev glacier constructed a moraine complex of sharp-crested lateral moraines enclosing a former tongue region of hummocky, ill-defined ridge sets at the terminus around 13.5-12 ka (Ivy-Ochs et al., 2009). Reconstruction of the surface of the Lagrev glacier (Fig. 5) implementing an ArcGIS automated tool (Pellitero et al., 2015) indicates an ELA depression of $220 \mathrm{~m}$ in comparison to the LIA ELA. The Great Aletsch glacier built single-walled, long, continuous lateral moraines during the Egesen stadial. The end position is poorly defined as the terminus was located within the Rhone valley. ${ }^{10} \mathrm{Be}$ exposure dates from boulders on the left-lateral moraine yield ages of $12 \pm 1$ ka (Kelly et al., 2004b). In contrast, the nearby and much smaller Belalp glacier fluctuated markedly building up at least four nested Egesen stadial moraines between 13-11.5 ka (Schindelwig et al., 2011). Moraines of glacier stabilization phases correlative to the Egesen stadial are reported from the southwestern Alps (Federici et al., 2009; Cossart et al., 2010; Darnault et al., 2011).

In some valleys a moraine can be found between the Egesen moraines and the LIA moraines. These moraines record a glacier advance to just a few hundred meters further downvalley than the LIA extent, with an ELA depression of about $120 \mathrm{~m}$ (Kartell stadial) 
(Ivy-Ochs et al., 2009). The Kartell moraine stabilized at around 11.9 ka suggesting it is related to the final phases of the Egesen stadial (Egesen III, Maisch, 1987). The left lateral moraine of the Tsidjiore Nouve glacier located just out side the LIA lateral moraine complex stabilized at $11.4 \mathrm{ka}$ (Schimmelpfennig et al., 2012). These glacier advances, smaller in extent than during the Egesen, may relate to the Preboreal Oscillation (PBO) when cool and humid conditions struck Europe (11,300-11,150 cal BP) (Bjorck et al., 1997). In other valleys, the intermediate moraines have been dated to about $10.5 \mathrm{ka}$, for example at Belalp near the Great Aletsch glacier (Schindelwig et al., 2011) and at Stein glacier (Schimmelpfennig et al., 2014) (locations shown in Fig. 2). In the latter case the terminal position is difficult to identify, hampering glacier reconstruction and ELA calculation. This cold pulse may correspond to CE-1 an early Holocene cold phase identified in paleobotanical records (Haas et al., 1998; Ivy-Ochs et al., 2009; Solomina et al., 2015).

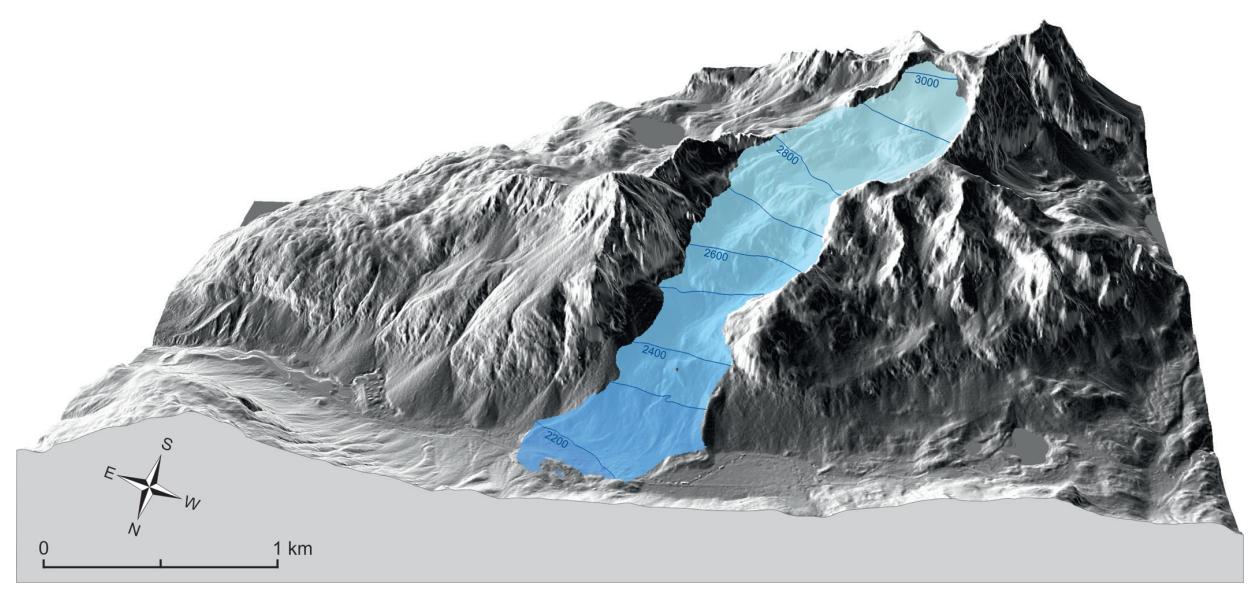

Figure 5. Reconstruction of the Lagrev glacier at Julier Pass during the Egesen stadial (location shown in Fig. 2). Glacier reconstruction with an ArcGIS toolbox (Pellitero et al., 2015) based on the equilibrium profile model of Benn and Hulton (2010). The determined equilibrium line altitude of the glacier was $2550 \mathrm{~m}$ a.s.l., giving a $\triangle E L A$ of $-220 \mathrm{~m}$ in comparison to the LIA ELA. Note that the contour lines of the glacier surface have not yet been adjusted for concave shape above the equilibrium line and convex shape below it.

During cold periods associated with the Lateglacial stadials, in regions of the Alps with suitable topoclimatological conditions, especially in areas where the cirque floor or rockwall niche was below the regional ELA (Zasadni, 2007), rock glaciers developed (Kerschner, 1978; Kellerer-Pirklbauer et al., 2012). Relict rock glaciers several hundred meters below the present lower limit of discontinuous permafrost likely formed during the closing phase of the Egesen stadial (Kerschner, 1978; Maisch, 1987). Relict rock glaciers at even lower elevations may have formed already during the early Lateglacial, becoming relict as temperatures were no longer conducive at that elevation. ${ }^{10} \mathrm{Be}$ dating of rock glaciers of the former category at Julier Pass and in the Larstig valley near Ötztal (Fig. 2) (Ivy-Ochs et al., 2009) shows that conditions remained cold yet became drier in 
the footprint of Egesen stadial glaciers towards the end of the Younger Dryas (Cossart et al., 2010, 2012; Böhlert et al., 2011; Darnault et al., 2012).

\section{Discussion and conclusions}

In the overdeepened valleys, LGM glaciers likely attained ice thicknesses of 1500$2000 \mathrm{~m}$, for example on the order of $2000 \mathrm{~m}$ in the lower portion of the LGM Rhine glacier upstream of Lake Constance (Benz, 2003) and $2500 \mathrm{~m}$ in the Hohe Tauern region (Reitner, 2013). On the northern forelands, piedmont lobes ranged in thickness to 400-700 m (Bini et al., 2009) depending on the elevation assumed for the glacier bed. The equilibrium line during the LGM maximum extent of the Rhine glacier has been estimated at $1000 \mathrm{~m}$ a.s.l. (Keller and Krayss, 2005) suggesting an ELA depression of more than $1500 \mathrm{~m}$ with respect to the LIA ELA of the catchment area (cf. Maisch et al., 2000). Benz (2003) calculated an LGM ELA of $950 \mathrm{~m}$ a.s.l. based on an ArcGIS reconstruction of the LGM Rhine glacier. This suggests a mean annual air temperature of -5.5 degrees compared to 8 degrees (between 1931-1960) and summer temperature of 3.2 degrees instead of 17.6 for Zurich (Benz, 2003).

Can the ice margin fluctuations of the LGM recorded at sites on either side of the Alps be correlated north to south? Brief advances to positions just beyond ('Maximalstand' of van Husen, 1997) the main LGM maximum positions ('Hochstand' of van Husen, 1997) during the LGM ice build-up phase have been discussed (van Husen, 1997, 2000; van Husen and Reitner, 2011) for the Austrian sector and for the Swiss sector (Keller and Krayss, 2005; Graf, 2009). Lack of dating control for this outermost stage hinders evaluation of its potential correlation to the well-dated Santa Margherita phase at Tagliamento (Monegato et al., 2007). It seems reasonable that the exposure ages pinpointing initiation of withdrawal from the maximum positions at $24 \pm 2 \mathrm{ka}$ the Rhone glacier (Ivy-Ochs et al., 2004) and at 22 \pm 1 ka at the Reuss glacier (Reber et al., 2014) correspond to the end of the period of occupation of the Tagliamento Santa Margherita phase (26.5-23 ka, Monegato et al., 2007; Ravazzi et al., 2012, 2014; Gianotti et al., 2015). Starnberger et al. (2011) correlate the second LGM advance phase of the Salzach glacier to the Candusso re-advance at Tagliamento (24-21 ka). Speculation suggests that the Tagliamento Remanzzaca phase, which ended at $19 \mathrm{ka}$, would then overlap in time with the Zurich re-advance stadial of the Linth-Rhine glacier, which ended no later than $18 \mathrm{ka}$ (Lister, 1988). The two major advances of the LGM maximum and the subsequent inner recessional moraine complexes found at the Tagliamento amphitheatre at this moment can be only loosely connected to the advances in the north. The inner LGM stadials of the northern side are spread somewhat farther behind the outermost maximum moraines (up to ca. $50 \mathrm{~km}$ ) than on the southern side of the Alps where outer, older arcs of moraines of the amphitheatres may have hindered expansion. Huge differences in catchment extent and hypsometry, ice volume, and lateral extent on the forelands must be taken into account.

LGM glaciers vanished rapidly from the forelands. A small increase in ELA, perhaps related to the slight warming of the Längsee oscillation around 19-18.5 ka (Schmidt et al., 2009), forced the long-flat foreland tongues to collapse catastrophically (Reitner, 
2013). Lakes formed in the narrow, overdeepened valleys at some sites glacially dammed on the upstream ends. Glacier downwasting may have been enhanced by calving into the lakes (van Husen, 2000, 2004; van Husen and Reitner, 2011). This is true for both the northern as well as the southern valleys. Scapozza et al. (2015) note that during the early Lateglacial Cugnasco stadial the Ticino glacier was calving into the paleo-lake Verbano.

Valley glaciers re-advanced during the Gschnitz stadial. Systems of interconnected dendritic glaciers likely still existed (Ivy-Ochs et al., 2006). By that time, 17-16 ka, more than $80 \%$ of the LGM ice volume was gone (van Husen, 1997). The Gschnitz stadial corresponds in time to the early phase of the Längsee cold period noted in southern Austrian lake sediments (Schmidt et al., 2009, 2012), as well as the Ragogna cold oscillation recognized at sites in the Tagliamento amphitheatre (Monegato et al., 2007). Summer temperature during the Gschnitz stadial was 8-10 degrees colder than today, with precipitation reduced by $25-50 \%$ (Kerschner, 2009; Schmidt et al., 2009). By the beginning of the Bølling interstadial much of the Alps were free of ice.

Glaciers re-advanced all across the Alps in response to the Younger Dryas cold period building up Egesen stadial moraines. In Figure 6, a longitudinal profile through Haslital (Fig. 2) for the reconstructed LGM, Gschnitz, and Egesen stadial glaciers allows comparison of the ice surface elevations. During the Egesen, temperatures were 3.5 or up to 5 degrees colder than today, depending on the precipitation values assumed, which may have been just slightly or markedly lower than today (up to 30\%), respectively (Kerschner et al., 2000; Kerschner and Ivy-Ochs, 2008; Kerschner, 2009). Chironimidbased July temperature reconstructions from sites across the Alps point to a temperature depression of 3.5 to 4 degrees for the Younger Dryas, with the first half about 1 degree colder at some sites (Heiri et al., 2014 and references therein). As Egesen glaciers downwasted the continued cold conditions but decreasing precipitation sums led to the development of rock glaciers in the former tongue regions. Moraines that are upvalley and morphologically distinct from Egesen stadial moraines may record positions of glacier stabilization during the Preboreal oscillation (Kartell stadial; Kerschner, 2009). A final glacier advance around $10.5 \mathrm{ka}$ was recorded at Belalp (Schindelwig et al., 2011) and at Stein glacier (Schimmelpfennig et al., 2014). This represents the last advance before glaciers in the Alps attained a size as small or smaller than today and remained so until the late Holocene (Ivy-Ochs et al., 2009; Solomina et al., 2015).

There are three important climatic cornerstones of termination I in the Alps. The first is the moment of deglaciation, corresponding to massive downwasting on both sides of the Alps. This may be set at about $20 \mathrm{ka}$ but no later than $19 \mathrm{ka}$. The second cornerstone is the Gschnitz stadial, 17-16 ka. It is the first true re-advance of glaciers after ice decay and marks an Alpine wide climatic deterioration tracked in both paleobotanical as well as glacial morphologic patterns. Our knowledge of the Gschnitz stadial must be underpinned by detailed mapping and more dates. Only then can the patterns of glacier extent and ELA depression be revealed. This goal has been impaired by the lack of sites suitable for dating with ${ }^{10} \mathrm{Be}$, and lack of material for ${ }^{14} \mathrm{C}$ dating directly related to the moraines. The third cornerstone is the Egesen stadial. As the moraines constructed during this stadial are typically blocky, this stadial has been dated with ${ }^{10} \mathrm{Be}$ at sites 
ranging from the Maritime Alps in the southwest to the Tauern region in the Eastern Alps (Bichler et al., submitted). Nevertheless, many questions remain about the timing and structure of deglaciation. Details on events during the phase of early Lateglacial ice decay are known from only a few regions. Finally, the late Pleistocene/Holocene transition displays an interesting pattern; cold oscillations represented by glacier advances to positions between the Egesen and LIA extents, as well as rock glacier activity, appear to have lasted until about $10.5 \mathrm{ka}$. Although a coherent picture is emerging there are still time ranges that require further study to bring them into focus.

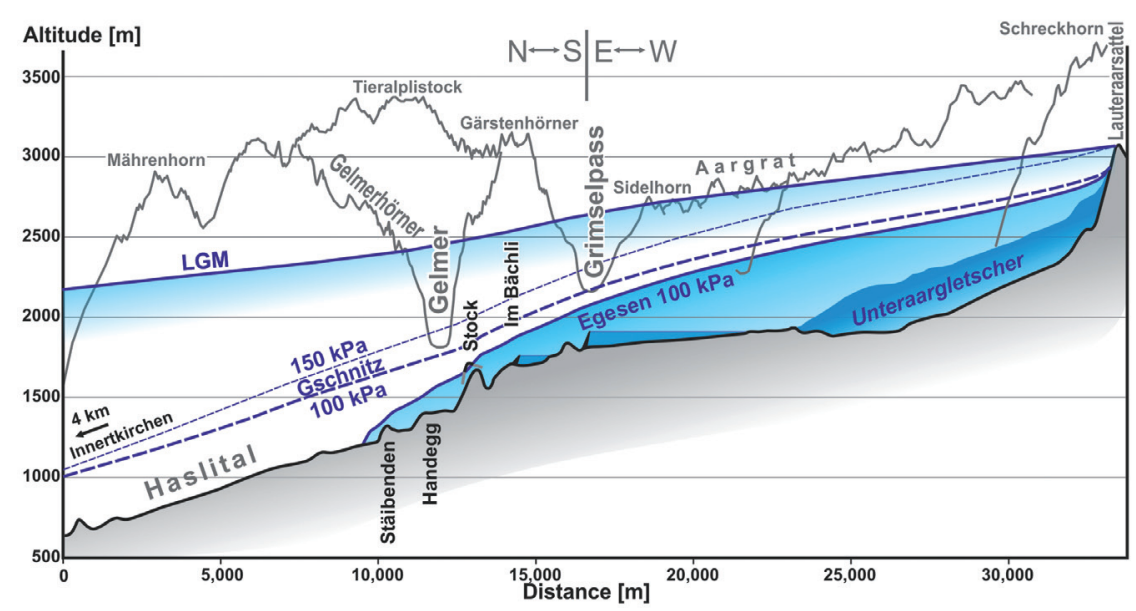

Figure 6. Longitudinal section through the Haslital from Grimsel Pass (location in Fig. 2, 3) showing reconstructed ice surfaces during the LGM, Gschnitz, and Egesen stadials (modified from Wirsig et al., submitted). Ice-surface elevation based on field mapping of ice flow direction indicators (striae, crescentic gouges), ${ }^{10}$ Be surface exposure dating, and ice flow modelling with the indicated basal shear stress values (Wirsig et al., submitted). Note the change in the trace of the profile from north-south to east-west at Grimsel Pass.

\section{Acknowledgements}

I would like to thank K. Hippe, R. Pellitero, C. Wirsig, and J. Zasadni for help with figures and for allowing me to use figures from submitted manuscripts. The constructive suggestions of two anonymous reviewers are acknowledged. This paper benefitted from discussion with members of the INQUA working group "Circumalpine events and correlations during the late Pleistocene" and with members of the Leverhulme Trust International funded network "Using glacier-climate proxies to model the Younger Dryas climate in Europe." I would like to thank D. Palacios for organizing this special issue. The overwhelming enthusiasm for Quaternary Geology shown by all members of the ETH Ion Beam Physics group is greatly appreciated. 
Ivy-Ochs

\section{References}

Ammann, B., Lotter, A.F., Eicher, U., Gaillard, M.J., Wohlfarth, B., Haeberli, W., Lister, G., Maisch, M., Niessen, F., Schlüchter, C. 1994. The Würmian Late-glacial in Iowland Switzerland. Journal of Quaternary Science 9, 119-125.

Ammann, B., van Raden, U.J., Schwander, J., Eicher, U., Gilli, A., Bernasconi, S.M., van Leeuwen, J.F.N., Lischke, H., Brooks, S.J., Heiri, O., Nováková, K., van Hardenbroek, M., von Grafenstein, U., Belmecheri, S., van der Knaap, W.O., Magny, M., Eugster, W., Colombaroli, D., Nielsen, E., Tinner, W., Wright, H.E. 2013. Responses to rapid warming at Termination 1a at Gerzensee (Central Europe): Primary succession, albedo, soils, lake development, and ecological interactions. Palaeogeography, Palaeoclimatology, Palaeoecology 391, 111-131.

Balco, G., Briner, J., Finkel, R., Rayburn, J., Ridge, J., Schaefer, J. 2009. Regional beryllium-10 production rate calibration for late-glacial northeastern North America. Quaternary Geochronology 4, 93-107.

Baroni, C., Martino, S., Salvatore, M.C., Mugnozza, G.S., Schilirò, L. 2014. Thermomechanical stress-strain numerical modelling of deglaciation since the Last Glacial Maximum in the Adamello Group (Rhaetian Alps, Italy). Geomorphology 226, 278-299.

Benn, D.I., Hulton, N.R.J. 2010. An Excel ${ }^{\mathrm{TM}}$ spreadsheet program for reconstructing the surface profile of former mountain glaciers and ice caps. Computers \& Geosciences 36, 605-610.

Benz, C. 2003. Der würmeiszeitliche Rheingletscher-Maximalstand. Digitale Rekonstruktion, Modellierung und Analyse mit einem Geographischen Informationssystem. Dissertation Geographisches Institut Universität Zürich, 180 pp.

Bichler, M.G., Reindl, M., Reitner, J., Wirsig, C., Christl, M., Ivy-Ochs, S. (submitted). Chronology and sedimentary records of glaciers and landslides before, during and after the Younger Dryas in the central part of the Eastern Alps. Boreas.

Bini, A., Buoncristiani, J.F., Couterrand, S., Ellwanger, D., Felber, M., Florineth, D., Graf, H.R., Keller, O., Kelly, M., Schlüchter, C., Schöneich, P. 2009. Die Schweiz während des letzteiszeitlichen Maximums (LGM), karte 1:500 000. Federal Office of Topography swisstopo, Wabern, Switzerland.

Björck, S., Rundgren, M., Ingolfsson, O., Funder, S. 1997. The Preboreal oscillation around the Nordic Seas: terrestrial and lacustrine responses. Journal of Quaternary Science 12, 455 465.

Böhlert, R., Egli, M., Maisch, M., Brandová, D., Ivy-Ochs, S., Kubik, P.W., Haeberli, W. 2011. Application of a combination of dating techniques to reconstruct the Lateglacial and early Holocene landscape history of the Albula region (eastern Switzerland). Geomorphology 127, $1-13$.

Buoncristiani, J.F., Campy, M. 2011. Quaternary glaciations in the French Alps and Jura. In Quaternary Glaciations-Extent and Chronology, J. Ehlers, P Gibbard (eds.), Elsevier, Amsterdam, pp. 117-126.

Burga, C.A. 1988. Swiss vegetation history during the last 18000 years. New Phytologist 110, 581-662.

Carton, A., Bondesan, A., Fontana, A., Meneghel, M., Miola, A., Mozzi, P., Primon, S., Surian, N. 2009. Geomorphological evolution and sediment transfer in the Piave River watershed (north-eastern Italy) since the LGM. Géomorphologié: Relief, Processus, Environnement 3, 37-58.

Clark, P.U., Dyke, A.S., Shakun, J.D., Carlson, A.E., Clark, J., Wohlfarth, B., Mitrovica, J.X., Hostetler, S.W., McCabe, A.M. 2009. The Last Glacial Maximum. Science 325, 710-714.

Cossart, E., Fort, M., Bourlès, D., Braucher, R., Perrier, R., Siame, L. 2012. Deglaciation pattern during the Lateglacial/Holocene transition in the southern French Alps. Chronological 
data and geographical reconstruction from the Clarée Valley (upper Durance catchment, southeastern France). Palaeogeography, Palaeoclimatology, Palaeoecology 315, 109-123.

Cossart, E., Fort, M., Bourlès, D., Carcaillet, J., Perrier, R., Siame, L., Braucher, R. 2010. Climatic significance of glacier retreat and rockglaciers re-assessed in the light of cosmogenic dating and weathering rind thickness in Clarée Valley (Briançonnais, French Alps). Catena 80, 204-219.

Coutterand, S., Buoncristiani, J.F. 2006. Paléogéographie du dernier maximum glaciaire du Pléistocène récent de la région du massif du Mont Blanc, France. Quaternaire. Revue de l'Association française pour l'étude du Quaternaire 17, 35-43.

Coutterand, S., Nicoud, G. 2005. Les stades de retrait du glacier de l'Arve entre le verrou de cluses et l'ombilic de Chamonix au cours du Tardiglaciaire (Vallée de l'Arve, Haute-Savoie). Quaternaire. Revue de l'Association française pour l'étude du Quaternaire 16, 85-94.

Coutterand, S., Schoeneich, P., Nicoud, G. 2009. Le lobe glaciaire lyonnais au maximum würmien: glacier du Rhône ou/et glaciers savoyard?. Neige et glace de montagne. Reconstitution, Dynamique, Pratiques (8), 11-22.

Darnault, R., Rolland, Y., Braucher, R., Bourlès, D., Revel, M., Sanchez, G., Bouissou, S. 2012. Timing of the last deglaciation revealed by receding glaciers at the Alpine-scale: impact on mountain geomorphology. Quaternary Science Reviews 31, 127-142.

Dielforder, A., Hetzel, R. 2014. The deglaciation history of the Simplon region (southern Swiss Alps) constrained by ${ }^{10} \mathrm{Be}$ exposure dating of ice-molded bedrock surfaces. Quaternary Science Reviews 84, 26-38.

Durst Stücki, M., Schlunegger, F. 2013. Identification of erosional mechanisms during past glaciations based on a bedrock surface model of the central European Alps. Earth Planetary Science Letters 384, 57-70.

Ehlers, J., Gibbard, P.L. 2004. Quaternary Glaciations-Extent and Chronology: Part I: Europe. Elsevier, Amsterdam.

Federici, P.R., Ribolini, A., Spagnolo, M. (submitted). The glacial history of the Maritime Alps. A complete chronosequence of glacial deposits in a same valley system. In P.D. Hughes, J.C. Woodward (eds.), Quaternary Glaciation in the Mediterranean, Geological Society of London, Special Publication.

Federici, P.R., Granger, D.E., Ribolini, A., Spagnolo, M., Pappalardo, M., Cyr, A.J. 2012. Last Glacial Maximum and the Gschnitz stadial in the Maritime Alps according to ${ }^{10} \mathrm{Be}$ cosmogenic dating. Boreas 41, 277-291.

Federici, P.R., Granger, D.E., Pappalardo, M., Ribolini, A., Spagnolo, M., Cyr, A.J. 2007. Exposure age dating and equilibrium line altitude reconstruction of an Egesen moraine in the Maritime Alps, Italy. Boreas 37, 245-253.

Fiebig, M., Ellwanger, D., Doppler, G. 2011. Pleistocene Glaciations of Southern Germany. Developments in Quaternary Science 15, 1-11. In J. Ehlers, P.L. Gibbard, P.D. Hughes (eds.), Quaternary Glaciations-Extent and Chronology: A Closer Look, Elsevier, Amsterdam, pp. 163-173.

Fiore, J., Girardclos, S., Pugin, A., Gorin, G., Wildi, W. 2011. Würmian deglaciation of western Lake Geneva (Switzerland) based on seismic stratigraphy. Quaternary Science Reviews 30, 377-393.

Florineth, D., Schlüchter, C. 1998. Reconstructing the Last Glacial Maximum (LGM) ice surface geometry and flowlines in the Central Swiss Alps. Eclogae Geologicae Helvetiae 91, 391407.

Florineth, D., Schlüchter, C. 2000. Alpine evidence for atmospheric circulation patterns in Europe during the Last Glacial Maximum. Quaternary Research 54, 295-308. 
Fontana, A., Mozzi, P., Marchetti, M. 2014a. Alluvial fans and megafans along the southern side of the Alps. Sedimentary Geology 301, 150-171.

Fontana, A., Monegato, G., Zavagno, E., Devoto, S., Burla, I., Cucchi, F. 2014b. Evolution of an Alpine fluvioglacial system at the LGM decay: the Cormor Megafan (NE Italy). Geomorphology 204, 136-153.

Gianotti, F., Forno, M.G., Ivy-Ochs, S., Kubik, P.W. 2008. New chronological and stratigraphical data on the Ivrea amphitheatre (Piedmont, NW Italy). Quaternary International, 190, 123135.

Gianotti, F., Forno, M.G., Ivy-Ochs, S., Monegato, G., Pini, R., Ravazzi, C. 2015. Stratigraphy of the Ivrea morainic amphitheatre (NW Italy) an updated synthesis. Alpine and Mediterranean Quaternary 28, 29-58.

Girardclos, S., Fiore, J., Rachoud-Schneider, A.M., Baster, I., Wildi, W. 2005. Western Lake Geneva climate history from deglaciation to present: a synthesis. Boreas 34, 417-433.

Graf, H.R. 2009. Stratigraphie von Mittel- und Spätpleistozän in der Nordschweiz. Beiträge zur Geologischen Karte der Schweiz, 168, Bundesamt für Landestopografie Swisstopo, Wabern.

Graf, H.R., Müller, B. 1999. Das Quartär: Die Epoche der Eiszeiten. In Geologie des Kantons Zürich, T. Bolliger (ed.). Ott Verlag, Thun, pp. 71-95.

Gross, G, Kerschner, H, Patzelt, G. 1977. Methodische Untersuchungen über die Schneegrenze in alpinen Gletschergebieten. Zeitschrift für Gletscherkunde und Glazialgeologie 12, 223-251.

Haas, J.N., Richoz, I., Tinner, W., Wick, L. 1998. Synchronous Holocene climatic oscillations recorded on the Swiss Plateau and at timberline in the Alps. The Holocene 8, 301-309.

Hantke, R. 1978-1983. Eiszeitalter (3 volumes). Ott, Thun.

Heiri, O., Koinig, K.A., Spötl, C., Barrett, S., Brauer, A., Drescher-Schneider, R., Gaar, D., IvyOchs, S., Kerschner, H., Luetscher, M., Moran, A., Nicolussi, K., Preusser, F., Schmidt, R., Schoeneich, P., Schwörer, C., Sprafke, T., Terhorst, B., Tinner, W. 2014. Palaeoclimate records $60-8 \mathrm{ka}$ in the Austrian and Swiss Alps and their forelands. Quaternary Science Reviews 106, 186-205.

Hinderer, M. 2001. Late Quaternary denudation of the Alps, valley and lake fillings and modern river loads. Geodinamica Acta 14, 231-263.

Hippe, K., Ivy-Ochs, S., Kober, F., Zasadni, J., Wieler, R., Wacker, L., Kubik, P.W., Schlüchter, C. 2014. Chronology of Lateglacial ice flow reorganization and deglaciation in the Gotthard Pass area, Central Swiss Alps, based on cosmogenic ${ }^{10} \mathrm{Be}$ and in $s i t u{ }^{14} \mathrm{C}$. Quaternary Geochronology 19, 14-26.

Huber, K., Weckström, K., Drescher-Schneider, R., Knoll, J., Schmidt, J., Schmidt, R. 2010. Climate changes during the last glacial termination inferred from diatom-based temperatures and pollen in a sediment core from Längsee (Austria). Journal of Paleolimnology 43, 131-147.

Hughes, P.D., Gibbard, P.L., Ehlers, J. 2013. Timing of glaciation during the last glacial cycle: evaluating the concept of a global 'Last Glacial Maximum' (LGM). Earth-Science Reviews $125,171-198$.

Ivy-Ochs, S., Kerschner, H., Kubik, P.W., Schlüchter, C. 2006. Glacier response in the European Alps to Heinrich Event 1 cooling: the Gschnitz stadial. Journal of Quaternary Science 21, 115-130.

Ivy-Ochs, S., Schäfer, J., Kubik, P.W., Synal, H.-A., Schlüchter, C. 2004. The timing of deglaciation on the northern Alpine foreland (Switzerland). Eclogae Geologicae Helvetiae 97, 47-55.

Ivy-Ochs, S., Kerschner, H., Maisch, M., Christl, M., Kubik, P.W., Schlüchter, C. 2009. Latest Pleistocene and Holocene glacier variations in the European Alps. Quaternary Science Reviews 28, 2137-2149.

Kellerer-Pirklbauer, A., Lieb, G.K., Kleinferchner, H. 2012. A new rock glacier inventory of the Eastern European Alps. Austrian Journal of Earth Science 105, 78-93. 
Keller, O, Krayss, E. 2005. Der Rhein-Linth Gletscher im letzten Hochglazial. 2. Teil: Datierung und Modelle der Rhein-Linth-Vergletscherung, Klimarekonstruktionen. Vierteljahresschrift der Naturforschenden Gesellschaft in Zürich 150, 69-85.

Keller, O., Krayss, E. 2010. Mittel- und spätpleistozäne Stratigraphie und Morphogenese in Schlüsselregionen der Nordschweiz. Quaternary Science Journal 59, 88-119.

Kelly, M.A., Buoncristiani, J.F., Schlüchter, C. 2004a. A reconstruction of the last glacial maximum (LGM) ice-surface geometry in the western Swiss Alps and contiguous Alpine regions in Italy and France. Eclogae Geologicae Helvetiae 97, 57-75.

Kelly, M.A., Ivy-Ochs, S., Kubik, P.W., Blanckenburg, F.V., Schlüchter, C. 2006. Chronology of deglaciation based on ${ }^{10} \mathrm{Be}$ dates of glacial erosional features in the Grimsel Pass region, central Swiss Alps. Boreas 35, 634-643.

Kelly, M.A., Kubik, P.W., von Blanckenburg, F., Schlüchter, C. 2004b. Surface exposure dating of the Great Aletsch Glacier Egesen moraine system, western Swiss Alps, using the cosmogenic nuclide ${ }^{10} \mathrm{Be}$. Journal of Quaternary Science 19, 431-441.

Kerschner, H. 1978. Paleoclimatic inferences from Late Würm rock glaciers, eastern central Alps, western Tyrol, Austria. Arctic and Alpine Research 10, 635-644.

Kerschner, H. 2009. Gletscher und Klima im Alpinen Spätglazial und frühen Holozän. In R. Schmidt, C. Matulla, R. Psenner (eds.), Klimawandel in Österreich. Die letzten 20,000 Jahre und ein Blick voraus. Innsbruck University Press, pp. 5-26.

Kerschner, H., Ivy-Ochs, S. 2008. Palaeoclimate from glaciers: Examples from the Eastern Alps during the Alpine Lateglacial and early Holocene. Global and Planetary Change 60, 58-71.

Kerschner, H., Kaser, G., Sailer, R. 2000. Alpine Younger Dryas glaciers as paleo-precipitation gauges. Annals of Glaciology 31, 80-84.

Klasen, N., Fiebig, M., Preusser, F., Reitner, J.M., Radtke, U. 2007. Luminescence dating of proglacial sediments from the Eastern Alps. Quaternary International 164-165, 21-32.

Krüger, T. 2008. Die Entdeckung der Eiszeiten, Internationale Rezeption und Konsequenzen für das Verständnis der Klimageschichte. Schwabe Verlag, Basel, 619 pp.

Kuhlemann, J., Rahn, M. 2013. Plio-Pleistocene landscape evolution in Northern Switzerland. Swiss Journal of Geosciences 106, 451-467.

Lambeck, K., Rouby, H., Purcell, A., Sun, Y., Sambridge, M. 2014. Sea level and global ice volumes from the Last Glacial Maximum to the Holocene. Proceedings of the National Academy of Sciences 111, 15296-15303.

Lister, G.S. 1988. A 15,000-year isotopic record from Lake Zürich of deglaciation and climatic change in Switzerland. Quaternary Research 29, 129-141.

Lotter, A.F., Eicher, U., Birks, H.J.B., Siegenthaler, U. 1992. Late Glacial climatic oscillations as recorded in Swiss lake sediments. Journal of Quaternary Science 7, 187-204.

Lotter, A.F., Heiri, O., Brooks, S., van Leeuwen, J.F.N., Eicher, U., Ammann, B. 2012. Rapid summer temperature changes during Termination 1a: high-resolution multi-proxy climate reconstructions from Gerzensee (Switzerland). Quaternary Science Reviews 36, 103-113.

Maisch, M. 1987. Zur Gletschergeschichte des alpinen Spätglazials: Analyse und Interpretation von Schneegrenzdaten. Geographica Helvetica 42, 63-71.

Maisch, M., Wipf, A., Denneler, B., Battaglia, J., Benz, C. 2000. Die Gletscher der Schweizer Alpen. Gletscherhochstand 1850, Aktuelle Vergletscherung, Gletscherschwund-Szenarien, vdf-Verlag, Zürich.

Mayr, F., Heuberger, H. 1968. Type areas of Late Glacial and Post Glacial deposits in Tyrol, eastern Alps, In G.M. Richmond (ed.), Glaciation of the Alps, University of Colorado Studies, Series in Earth Sciences 7, pp. 143-165. 
Ivy-Ochs

Monegato, G., Ravazzi, C., Donegana, M., Pini, R., Calderoni, G., Wick, L. 2007. Evidence of a two-fold glacial advance during the last glacial maximum in the Tagliamento end moraine system. Quaternary Research 68, 284-302.

Müller, B.U. 1999. Paraglacial sedimentation and denudation processes in an Alpine valley of Switzerland. An approach to the quantification of sediment budgets. Geodinamica Acta 12, 291-301.

Ndiaye, M., Clerc, N., Gorin, G., Girardclos, S., Fiore, J. 2014. Lake Neuchâtel (Switzerland) seismic stratigraphic record points to the simultaneous Würmian deglaciation of the Rhône Glacier and Jura Ice Cap. Quaternary Science Reviews 85, 1-19.

Pedrazzini, A., Humair, F., Jaboyedoff, M., Tonini, M. 2015. Characterisation and spatial distribution of gravitational slope deformation in the Upper Rhone catchment (Western Swiss Alps). Landslides, 1-19.

Penck, A., Brückner, E. 1901/1909. Die Alpen im Eiszeitalter. Tauchnitz, Leipzig.

Pellitero, R., Rea, B.R., Spagnolo M., Bakke, J., Ivy-Ochs, S., Hughes, P., Lukas, S., Ribolini, A. 2015. A GIS tool for automatic calculation of glacier equilibrium-line altitudes. Computers and Geosciences.

Preusser, F., Reitner, J., Schlüchter, C. 2010. Distribution, geometry, age and origin of overdeepened valleys and basins in the Alps and their foreland. Swiss Journal of Geosciences 103, 407-426.

Preusser, F., Graf, H.R., Keller, O., Krayss, E., Schlühter, C. 2011. Quaternary glaciation history of northern Switzerland. Quaternary Science Journal 60, 282-305.

Ravazzi, C., Badino, F., Marsetti, D., Patera, G., Reimer, P.J. 2012. Glacial to paraglacial history and forest recovery in the Oglio glacier system (Italian Alps) between 26 and $15 \mathrm{ka} \mathrm{cal} \mathrm{BP.}$ Quaternary Science Reviews 58, 146-161.

Ravazzi, C., Pini, R., Badino, F., De Amicis, M., Londeix, L., Reimer, P.J. 2014. The latest LGM culmination of the Garda Glacier (Italian Alps) and the onset of glacial termination. Age of glacial collapse and vegetation chronosequence. Quaternary Science Reviews 105, 26-47.

Reber, R., Akcar, N., Ivy-Ochs, S., Tikhomirov, D., Burkhalter, R., Zahno, C., Lüthold, A., Kubik, P., Vockenhuber, C., Schlüchter, C. 2014. Deglaciation of the Reuss Glacier in the Alps at the end of the Last Glacial Maximum. Swiss Journal of Geosciences 107, 293-307.

Reimer, P.J., Bard, E., Bayliss, A., Beck, J.W., Blackwell, P.G., Bronk Ramsey, C., Buck, C.E., Cheng, H., Lawrence, E.R., Friedrich, M., Grootes, P.M., Guilderson, T.P., Haflidason, H., Hajdas, I., Hatté, C., Heaton, T.J., Hoffmann, D.L., Hogg, A.G., Hughen, K.A., Kaiser, K.F., Kromer, B., Manning, S.W., Niu, M., Reimer, R.W., Richards, D.A., Scott, E.M., Southon, J.R., Staff, R.A., Turney, C.S.M., van der Plicht, J. 2013. IntCal13 and Marine13 radiocarbon age calibration curves 0-50,000 years cal BP. Radiocarbon 55, 1869-1887.

Reitner, J.M. 2007. Glacial dynamics at the beginning of Termination I in the Eastern Alps and their stratigraphic implications. Quaternary International 164-165, 64-84.

Reitner, J.M. 2011. Das Inngletschersystem während des Würm-Glazial. In A. Gruber (ed.), Arbeitstagung 2011 der Geologischen Bundesanstalt Blatt 88 Achenkirch, Geologische Bundesanstalt, Wien, pp. 79-88.

Reitner, J.M. 2013. The effect of Climate Change during the Lateglacial in the Hohen Tauern. 5th Symposium for Research in Protected Areas, Conference Volume, 653-658.

Reitner, J., Gruber, W., Römer, A., Morawetz, R. 2010. Alpine overdeepenings and paleoice flow changes: an integrated geophysical-sedimentological case study from Tyrol (Austria). Swiss Journal of Geosciences 103, 385-405.

Scapozza, C., Castelletti, C., Soma, L., Dall'Agnolo, S., Ambrosi, C. 2015. Timing of LGM and deglaciation in the Southern Swiss Alps. Géomorphologie 4, 307-322. 
Schimmelpfennig, I., Schaefer, J.M., Akçar, N., Ivy-Ochs, S., Finkel, R.C., Schlüchter, C. 2012. Holocene glacier culminations in the Western Alps and their hemispheric relevance. Geology 40, 891-894.

Schimmelpfennig, I., Schaefer, J.M., Akçar, N., Koffman, T., Ivy-Ochs, S., Schwartz, R., Finkel, R.C., Zimmerman, S., Schlüchter, C. 2014. A chronology of Holocene and Little Ice Age glacier culminations of the Steingletscher, Central Alps, Switzerland, based on highsensitivity beryllium-10 moraine dating. Earth and Planetary Science Letters 393, 220-230.

Schindelwig, I., Akçar, N., Kubik, P.W., Schlüchter, C. 2011. Lateglacial and early Holocene dynamics of adjacent valley glaciers in the Western Swiss Alps. Journal of Quaternary Science 27, 114-124.

Schlüchter, C. 1988. A non-classical summary of the Quaternary stratigraphy in the northern alpine Foreland of Switzerland. Bulletin de la Société Neuchâteloise de Géographie 32, 143-157.

Schlüchter, C. 2004. The Swiss glacial record: a schematic summary. In J. Ehlers, P.L. Gibbard (eds.), Quaternary Glaciations: Extent and Chronology Part I: Europe, Elsevier, London, pp. 413-418.

Schlüchter, C., Röthlisberger, C. 1995. 100,000 Jahre Gletschergeschichte. In Gletscher im ständigen Wandel. vdf-Verlag ETH, Zürich, pp. 47-63.

Schmidt, R., Drescher-Schneider, R., Huber, K. Weckstöm, K. 2009. Die Bedeutung des Längsees in Kärnten für die Rekonstruktion der Klima- und Seenentwicklung am Ende der letzten Eiszeitt. In R. Schmidt, C. Matulla, R. Psenner (eds.) Klimawandel in Österreich. Die letzten 20,000 Jahre und ein Blick voraus, Innsbruck University Press, pp. 27-40.

Schmidt, R., Weckström, K., Lauterbach, S., Tessadri, R., Huber, K. 2012. North Atlantic climate impact on early late-glacial climate oscillations in the south-eastern Alps inferred from a multi-proxy lake sediment record. Journal of Quaternary Science 27, 40-50.

Shakun, J.D., Carlson, A.E. 2010. A global perspective on Last Glacial Maximum to Holocene climate change. Quaternary Science Reviews, 29, 1801-1816.

Starnberger, R., Rodnight, H., Spötl, C. 2011. Chronology of the last glacial maximum in the Salzach Palaeoglacier area (Eastern Alps). Journal of Quaternary Science 26, 502-510.

Solomina, O.N., Bradley, R.S., Hodgson, D.A., Ivy-Ochs, S., Jomelli, V., Mackintosh, A.N., Nesjei, A., Owen, L.A., Wanner, H., Wiles, G.C., Young, N.E. 2015. Holocene glacier fluctuations. Quaternary Science Reviews 111, 9-34.

van Husen, D. 1997. LGM and Late-glacial fluctuations in the Eastern Alps. Quaternary International 38/39, 109-118.

van Husen, D. 2000. Geological processes during the Quaternary. Mitteilungen der Österreichischen Geologischen Gesellschaft 92, 135-156.

van Husen, D. 2004. Quaternary glaciations in Austria. In Quaternary Glaciations: Extent and Chronology Part I: Europe, J. Ehlers J., P.L. Gibbard (eds.). Elsevier, London, pp. 1-13.

van Husen, D., Reitner, J.M. 2011. An outline of the Quaternary stratigraphy of Austria. Eiszeitalter und Gegenwart 60, 366-387.

van Husen, D., Ivy-Ochs, S., Alfimov, V. 2007. Mechanism and age of late glacial landslides in the Calcareous Alps; The Almtal, Upper Austria. Austrian Journal of Earth Sciences 100, 114-126.

von Poschinger, A., Haas, U. 1997. Der Flimser Bergsturz, doch ein warmzeitliches Ereignis? Bulletin für angewandte Geologie 2, 35-46.

Wirsig, C., Zasadni, J., Ivy-Ochs, S., Christl, M., Kober, F., Schlüchter, C. (submitted). A deglaciation model of the Oberhasli, Switzerland. Journal of Quaternary Science.

Zasadni, J. 2007. The Little Ice Age in the Alps: its record in glacial deposits and rock glacier formation. Studia Geomorphologica Carpatho-Balcanica 41, 117-137. 